\section{Between drought and disparity: American Indian farmers, resource bureaucracy, and climate vulnerability in the Southern Plains}

\author{
Special JAFSCD Issue \\ Indigenous Food Sovereignty in North America \\ sponsored by \\ Swette Center for
Sustainable Food Systems \\ Arizona State University
}

\author{
Tony N. VanWinkle a* \\ Sterling College \\ Jack Friedman ${ }^{b}$ \\ University of Oklahoma
}

Submitted June 20, 2019 / Revised September 8, October 29, and November 21 and 26, 2019 /

Accepted November 26, 2019 / Published online December 17, 2019

Citation: VanWinkle, T. N., \& Friedman, J. (2019). Between drought and disparity: American Indian farmers, resource bureaucracy, and climate vulnerability in the Southern Plains. Journal of Agriculture, Food Systems, and Community Development, 9(Suppl. 2), 53-68. https://doi.org/10.5304/jafscd.2019.09B.022

Copyright (C) 2019 by the Authors. Published by the Lyson Center for Civic Agriculture and Food Systems. Open access under CC-BY license.

\begin{abstract}
Based on research conducted with American Indian farmers and ranchers in southwestern Oklahoma, this paper interrogates how agricultural resource bureaucracies differentially constrain or enable resilience to climate variability. We demonstrate that while extreme weather events have been a persistent impediment to agriculture in the region, for American Indian farmers and ranchers, such efforts have been equally impeded by a history of negative interaction with opaque and fre-
\end{abstract}

a * Corresponding author: Tony N. VanWinkle, Faculty in Sustainable Food Systems; Director, Rian Fried Center for Sustainable Agriculture \& Food Systems; Sterling College; P.O. Box 72; Craftsbury Common, VT 05827 USA; tvanwinkle@sterlingcollege.edu

b Jack Friedman, Research Scientist, Center for Applied Social Research, University of Oklahoma; 5 Partners Place, 201 Stephenson Parkway, Suite 4100; Norman, OK 73019 USA; jack.r.friedman@ou.edu quently indifferent systems of overlapping, yet disjunctive, bureaucracy. Thus we are concerned with precisely how structural vulnerability and climate vulnerability are reproduced in tandem and how such structural constraints have circumscribed nascent food sovereignty efforts. Drawing on our research into how farmers in southwest Oklahoma understand the interaction between the impactspotential and/or experienced - of climate change and different relationships to agriculture and nature, we demonstrate how demoralization and social defeat emerge from the failures of local resource bureaucracies. Those agencies have, ironically, contributed to the vulnerability of the very population they have been established to serve. What we will show is that, caught between the opacity and bureaucratic posturing of two federal

\section{Funding Disclosure}

This material is based on work supported by the National Science Foundation under grant no. OIA-1301789. 
resource agencies, many American Indian landowners simply give up.

\section{Keywords}

Resource Bureaucracy, Agricultural Governance, Climate Variability, Vulnerability, American Indian Land

\section{Introduction}

In 2010, with the assistance of a regional nonprofit organization dedicated to helping American Indians secure the land and capital necessary to make a start at farming and/or ranching, a middle-aged woman and member of the Apache Tribe of Oklahoma, whom we will call Dana, decided to give ranching a try. She leased land from another Native landowner through the local office of the Bureau of Indian Affairs (BIA) and started a small cow-calf operation with a few purchased heifers. Things started off reasonably well, but then the first year of a severe multiyear drought struck. After several years of struggling to keep grass alive and cattle watered, Dana was finally forced to sell off her herd and relinquish her lease back to the BIA, which would offer it to the highest bidder at the next agency bid sale. Another participant, a longtime natural resource and agricultural consultant for tribes in western Oklahoma, said that this Plains Apache cattlewoman's fate was not uncommon among American Indian producers through the state's 2010-2014 drought cycle. As Dana put it, "There was a lot of them that had to ... go out of business and sell the cows and calves they had, because they didn't have the grass, or they didn't have the hay. They were out of feed, so they just had to get out."

Through this same drought period, many nonNative ranchers in the area went through considerable herd reductions as well, though they were generally able to maintain their livelihood as ranchers. Their capacity was due to a number of factors. First, many non-Native ranchers command a larger land base (though, ironically, a good deal of it is leased from American Indian landowners) that allows more extensive management practices. Second, these operations tend to have greater levels of capitalization and/or ready access to capital, which, on the one hand, insulates these ranchers from temporary losses, and/or, on the other, allows them to supplement their livestock with purchased hay or imported water. Third, non-Native producers tend to have greater access to the risk management and assistance apparatus historically administered through local United States Department of Agriculture (USDA) service centers, which house the offices of the Farm Service Agency (FSA), the Natural Resources Conservation Service (NRCS), and the local Soil and Water Conservation District (SWCD). This constellation of agencies is collectively characterized in this study as resource bureaucracies due to their mandate to oversee the federal, state, and local management of agricultural and natural resources, including water, soils, crop and livestock health, and other associated resources. The services these agencies administer, which range from conservation incentive and disaster relief programs to more basic information services concerning technical knowledge, crop insurance programs, application deadlines, and so forth, are indeed critical buffering mechanisms for farmers and ranchers in a region beset by extreme climate and weather events. By "buffering," we refer specifically to the "dynamic interaction of technology adjustment and social restructuring that links public policy, social institutions, and private decision making," as articulated by Vasquez-Leon, West, and Finnan (2003, p. 161). "This perception of 'being buffered' is linked to social class with the greater access to social capital, political power, entitlements, and other resources, where some of the individual risks associated with climate variability are shifted to a higher order of institutional support" (Vasquez-Leon et al., 2003, p. 161).

When we asked Dana about her ability to utilize these same buffering mechanisms, in the case of crop insurance, she responded, "The first year, we didn't know anything about it! There it went! The second year we did ask about it, but the deadline passed us ... Even though we went to them [the USDA service center], they weren't well informed on what dates they cut off and stuff. I guess you are supposed to know all that." Although her nonprofit partner would assist her in securing some relief through the FSA's livestock indemnity program, due to time lags between official drought declarations and payment allocations, 
it did not save her operation. In the framework of vulnerability offered by Vasquez-Leon, West, and Finnan, this condition, in contrast to buffering, can be thought of as coping, defined as "adjustments made by individuals and households with limited technological inputs and fragile public support [emphasis added]" (Vasquez-Leon et al., p. 161). Unlike buffering, "coping does not lead to an increased sense of security or the perception that a community is better prepared to deal with future climatic events" (Vasquez-Leon et al., p. 161). These experiences are further indicative of both the long history and the contemporary legacy of discriminatory treatment from local-level USDA service centers, a central focus of this paper.

Adding to the complexity of matters in southwestern Oklahoma is the additional bureaucratic apparatus attending the management of American Indian lands held in trust by the U.S. Department of Interior and administered by the local Agency of the Bureau of Indian Affairs (BIA). Indeed, as pernicious as the effects of drought have been on aspiring American Indian farmers and ranchers, this paper will demonstrate that just as prohibitive have been the effects of these often opaque and frequently indifferent systems of overlapping, yet disjunctive bureaucracies. In examining the attendant intersections, this paper is concerned with precisely the ways in which structural vulnerability and climate vulnerability are reproduced in tandem, even as attempts at both the federal and grassroots levels have attempted to ameliorate these conditions. In such a context, efforts towards food sovereignty utilizing American Indian-owned land are severely limited. Drawing on our research on how farmers in southwest Oklahoma understand the interaction between the impactspotential and/or experienced — of climate change and different relationships to agricultural and natural resource agencies we demonstrate how demoralization and social defeat emerge from the failures of these local resource bureaucracies. These agencies have, ironically, contributed to the vulnerability of the very populations that they have been established to serve. What we will show is that, caught between the opacity and bureaucratic posturing of two federal resource agencies (BIA and USDA), many American Indian landowners simply give up.

We will begin with a brief examination of the history of American Indian farming efforts in southwestern Oklahoma. This background will demonstrate that, though the proximate causes of American Indian farming challenges have often been climatological (i. e., drought), this trend has been compounded and intensified by a persistent lack of access to institutional resources and assistance. Then we will examine the contemporary history of discrimination endemic to the USDA, efforts by the agency to mitigate this reality, and the continuing problems that plague those efforts. We will then proceed to map ethnographic and archival evidence gathered in 2015-2016 from Caddo County in southwestern Oklahoma in order to illustrate the ways in which USDA policy initiatives for "socially disadvantaged farmers and ranchers" have been doomed to failure. Finally, we will look at the ways in which the combined legacies of discrimination and bureaucratic disjunction between the USDA and the BIA lead to an even greater level of social vulnerability among American Indian landowners. First, however, we will briefly explain the methodologies, data, and limitations that inform this study.

\section{Methodology and Study Limitations}

Results presented in this paper are based on ethnographic fieldwork conducted by the authors over 10 months (July 2015-May 2016) and draw on hundreds of hours of participant observation with farmers, ranchers, and other actors in local communities in the upper Washita River watershed in Oklahoma, as well as 59 semi-structured recorded interviews with 65 participants, participant observation and extensive field notation, and thousands of pages of archival documents. Regarding recruitment of interviewees, the study began with the recruitment of key informants, such as agricultural extension agents, members of agricultural co-ops, and participants in local Native American farming groups, who we already knew would be able to help us make contact with and select appropriate additional research participants, who, in turn, recommended other participants. Thus, interviewees were recruited via purposive snowball sampling. Supporting archival resources include the micro- 
film collections of Caddo County newspapers archived at the Anadarko Community Library, including The Anadarko Democrat, The Anadarko Tribune, The Anadarko Daily News, The Fort Cobb News, and The Apache Review. The transcribed interviews and field observations of the Doris Duke Collection, of the University of Oklahoma's Western History Collections, proved an invaluable source as well, providing temporal depth that complemented our own interviews and field observations.

While recorded interviews ranged from 60 to 180 minutes, as one of the authors was a full-time resident of the study area, it was not unusual to spend additional hours, days, or weeks with participants in a variety of settings. Extensive ethnographic field notes were recorded from observational contexts including farm, field, and agricultural production facility tours, attendance at meetings of local nonprofit and producer organizations, visits to the local USDA service center and county extension office, and regular attendance at tribal cultural events and gatherings. The authors have also worked with other agricultural research colleagues and local extension agents to regularly fact check and confirm that our interpretations of the data are reflective of actual conditions. Finally, USDA patterns of differential service delivery have been well documented in both internally produced reports and independent scholarly monographs. These primary and secondary documents add to the veracity of our observations here.

We would like to point out several limitations to this study, however. First, this is a qualitative, ethnographic study focused on the southwest portions of the state of Oklahoma. As with any qualitative study, this limits the conclusions that we can draw about how the situation of Oklahoman American Indians-who had a peculiar history regarding tribal land claims and sovereigntyresembles those of other U. S. tribes. Second, our discussion of racism is limited to what our data can empirically support. While individual research subjects reported individual acts of racism and discrimination, we primarily described structural racism due to limitations in the data available (i.e., the lack of reporting, experiences of undocumented racism that kept some American Indians from ever pursuing agriculture or receiving equal treatment by resource bureaucracies). Third, the study (i.e., the extended, in situ fieldwork) was carried out during the period 2015 to 2016, with occasional follow-up with research subjects occurring between 2016 and 2019. We were, therefore, not in a position to fully assess what, if any impacts, might have followed subsequent iterations of the farm bill. However, in follow-up meetings with our research subjects in 2019, they did not report a change in their perception regarding the challenges they face in farming and ranching in the region. Finally, one of the critical "actors" in this paper is the BIA. We believe that the role of the BIA in, at times, compounding the challenges American Indians face in entering and succeeding in agriculture is central. However, our study primarily focused on the experiences and perceptions of American Indian "end users" of BIA services and policies. The particularities of BIA policies and policy-making go beyond what can be included in this paper, but are a critical subject for future analysis.

\section{Background and Context: Vulnerabilities, Variability, and Extremes}

Caddo County's modern commercial agricultural economy effectively launched in 1901, when the former reservation territories of the Kiowa, Comanche, Apache (KCA) and Wichita, Caddo, Delaware (WCD) tribes were opened to white settlers. In the case of the KCA, the allotment period marked the closure of a reservation period precipitated by the Medicine Lodge Treaty of 1867 and the Red River War of 1874-1875. The latter events, ending with the Battle of Palo Duro Canyon, resulted in the forced march of the KCA tribes overland to Fort Sill in southwestern Oklahoma over the winter of 1874-1875, and their subsequent settlement on shared reservation lands south of the Washita River, part of which includes modern Caddo County. Although under different circumstances, the Wichitas found themselves, along with the Caddo and Delaware tribes, relocated to a reservation north of the Washita River in 1869, also encompassing part of modern Caddo County (the latter history is well documented in Smith, 1996).

In 1901, the combined reservation lands of the 
KCA and WCD tribes were opened to white settlers by lottery drawings. The lottery itself followed on the heels of allotment, a process initiated by the 1887 General Allotment Act, more commonly known as the Dawes Act, through which reformers hoped to accelerate the transformation of nomadic buffalo hunters and semi-sedentary villagers into independent yeoman farmers through the institution of private property. Thus every eligible tribal member was assigned a quarter section of land (160 acres or 65 hectares) on which to realize this chimera of cultural and socio-economic conversion. Leftover lands were designated "surplus," and open to non-Native settlement. This shift in land tenure precipitated an accompanying shift in the local agricultural economy, one that centered initially around cotton but which rapidly incorporated other key commodity crops including grain sorghum, wheat, and, by mid-century, peanuts.

These shifts toward capital-intensive commodity crops demanded expensive new harvesting technologies and practices that worked to exclude minority farmers even as the state's agri-governance apparatus (state land grant college outreach, USDA service offices, local soil and water conservation districts) began to coalesce around them (Lynn-Sherow, 2004). As Stahl (1978) notes, even despite the continued presence of agri-governance agencies, patterns of recurrent drought, economic marginalization, discrimination, and lack of institutional support have plagued American Indian farming efforts in the KCA/WCD jurisdictional areas since their inception in the reservation period. Indian agents recorded drought conditions in 15 of the reservation's 32 years of existence (Stahl, 1978, p. 178). As Stahl (1978) asserts, "Following the trauma of allotment, the major obstacles to American Indian farmers were drought, lack of farm instruction, inadequate farm tools, and a general shortage of capital" (p. 214)—a statement that has equal resonance for current American Indian farming efforts. Indeed, the erratic climatic conditions that beset would-be American Indian farmers in this early period is consistent with the general perception of Oklahoma as having some of the most significant weather extremes and variability in the U.S. Since historical records of precipitation first were kept in the state, extreme year-to-year fluctua- tion between pluvial and drought conditions have been experienced, often with extended periods of drought, most notably in the 1930s and 1950s (Figure 1).

What is critical to realize in the story that we tell below, however, is that for a number of historical, structural, and experiential causes, many of the most important buffering mechanisms that are available to contemporary farmers in the Great Plains are either unavailable or structurally difficult to access for many Native American farmers. As we will show, Native American farmers remain relatively undercapitalized, lack the same capacity to navigate bureaucracies often run by non-Natives, and are not able to "access" their own land (Ribot \& Peluso, 2009; VanWinkle \& Friedman, 2018) due to the nature of BIA land trust rules that make it almost impossible for them to act on an even playing field with other, non-Native farmers. The lack of capacity to access these and other buffering mechanisms put them at particular risk-making them more vulnerable to the climatological variability and extremes that are predicted to become the "new normal" in Oklahoma under climate change.

The contemporary experience of American Indian farmers is in many ways analogous to that of African American farmers in the U.S. South. Green, Green, and Kleiner (2011) and Jones (1994) note that African American farmers face problems of scale, mechanization, tenure insecurity, property disputes, market consolidation, limited access to timely and appropriate credit, and "limited knowledge of, participation in, and access to government agriculture programs" (p. 56). On this last point, the authors assert that "most of the prominent government agricultural programs were designed to provide the greatest benefits to those farmers with the highest level of commercial production rather than those in the greatest need of assistance" (2011, p. 56). Such conditions have led to a series of interventions (see below) by the USDA intended to ameliorate this situation, in the South and elsewhere.

With these considerations in mind, the intersecting vulnerabilities that we will describe in this paper will be (1) historic, represented in the problematic and dysfunctional system of land tenure/ 
Figure 1. Oklahoma's Annual Precipitation History with 5-Year Tendencies, Statewide, for 1895 to 2016

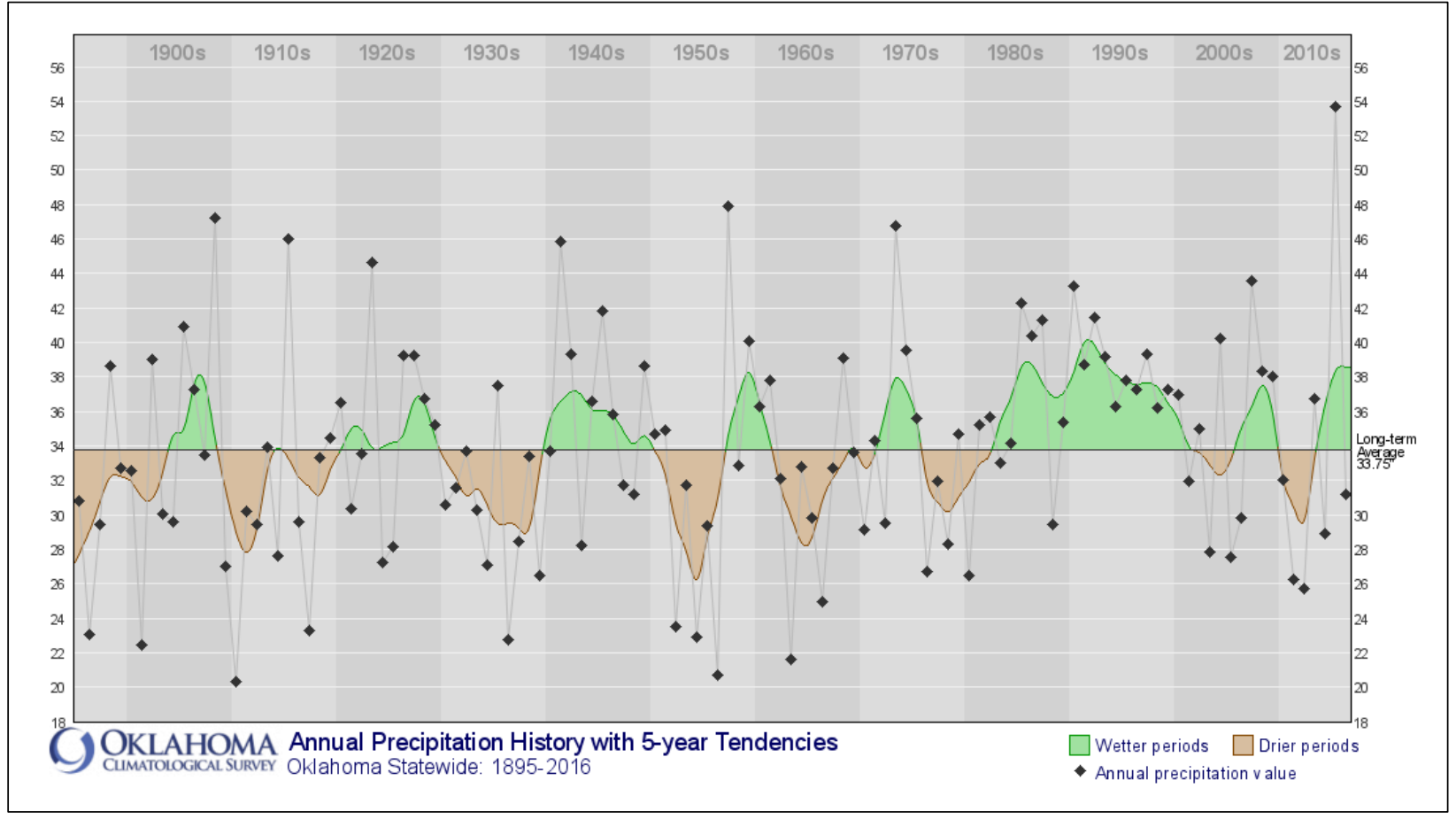

Source: Oklahoma Climatological Survey, n.d.

land access among Native American landowners; (2) climatological, represented in the special challenges, from a coupled human and natural systems standpoint, posed by the particularly extreme and variable nature of weather and climate patterns in Oklahoma; and (3) political-bureaucratic, represented in the disjuncture between the system of agri-bureaucracies in place to protect and support farmers and the inefficiencies and contradictions that functionally exclude Native American farmers in Caddo County from benefiting from the buffering efforts of those bureaucracies.

\section{Historical and Structural Vulnerabilities: Dysfunctional Bureaucratic Legacies and Native American Farmers}

The Commission on Civil Rights 1965 investigation of the USDA revealed the nature and extent of the department's history of discrimination in both program delivery and employment practices (U.S. CCR, 1965). Subsequent reports found that practices in the former category were a major contributor to the decline in minority farming and land ownership. As such patterns were initially thought to be most pervasive and severe in the South, such revelations earned the department the epithet, "The Last Plantation" (Mittal, 2000; USDA-CRAT, 1997). Characterized by a professional and agency culture of "passive nullification" (Daniel 2013), this history of minority exclusion dominated both the USDA and the state extension service through most of the 20th century. It was not until 1990 that the first provisions to rectify the problems of discriminatory practices at the USDA were codified in policy, in Section 2501 of the 1990 farm bill, otherwise known as the Outreach and Assistance to Socially Disadvantaged Farmers and Ranchers (OASDFR) program. As explained in a 2016 Congressional report on local food systems, the "2501 program," as it is commonly known, "requires the USDA to provide outreach and technical assistance to socially disadvantaged producers, defined as members of a group that has been subjected to racial or ethnic prejudice" (Johnson \& Cowan, 2016, p. 13).

Another series of events important in the evolution of the USDA civil rights history occurred in 1997, when Timothy Pigford, an African Ameri- 
can farmer from eastern North Carolina, filed a landmark class-action lawsuit on behalf of $400 \mathrm{fel}-$ low black farmers against the USDA. Settled two years later, Pigford $v$. Glickman became a template for subsequent challenges to the long history of USDA discrimination against minority farmers, including the parallel American Indian suit, Keepseagle v. Vilsack. Also in 1997, President Clinton commissioned a Civil Rights Action Team (CRAT) to investigate prior complaints and conduct listening sessions around the country, public forums where USDA "customers" could express complaints and grievances. The CRAT report confirmed that discrimination was rampant on both the personal and institutional levels: "Despite the fact that discrimination in program delivery and employment has been documented and discussed, it continues to exist to a large extent, unabated" (USDA-CRAT, 1997, p. 2). The department's status as "a huge decentralized bureaucracy," the report continues, is central to this condition: "Many of its agencies deliver programs through a large field office network in conjunction with local farmer boards which help direct how the programs are administered locally" (1997, p. 2).

Due to the nature of discriminatory practices within this decentralized bureaucratic structure, hard statistical data on specific instances of such behavior have been difficult to come by. A 2008 Government Accountability Office report asserts that while the USDA recognizes decades of discriminatory behavior in service delivery, statistical accounting of efforts to address this issue have been unreliable, "because USDA's data on racial identity and gender are, for the most part, based on visual observation of program applicants" (U.S. GAO, 2008, p. 5). Similarly, a 2011 third party USDA Civil Rights Assessment determined that while the USDA's internal investigations led to no findings of discrimination in over $97 \%$ of filed claims, this result is itself indicative of ineffectiveness arising from a combination of unreliable data, delays in processing, and failure to investigate complaints. Consistent with the structural discrimination framework of this paper, the 2011 Assessment found that delays in processing leading to backlogs and lengthy investigations contribute to faulty outcomes: "Delays sabotage the very purpose of an internal complaint system ... Delays in and of themselves undermine confidence in the process, enable complainants to assume the worst, and damage the integrity of fact finding" (Jackson Lewis LLP, Corporate Diversity Counseling Group, 2011, p. xxv). Indeed, this lack of empirical accountability remains a substantial barrier to the enactment of change in the agency's civil rights efforts.

One useful framework for analyzing the structure of USDA program delivery is through the lens of "capture theory," which holds that "an agency's clientele may come to control the agency thereby deflecting it from its mandated mission" (Fortmann, 1990, p. 362). Decentralized agencies with locally elected directorate boards are particularly susceptible to capture by a homogeneous clientele, such as a Bureau of Land Management (BLM) case discussed by Fortmann. The BLM's boards were initially composed of ranchers nominated by other ranchers, whose group interests came to define the administrative and service delivery apparatus of local BLM offices. Such situations create scenarios with "clear influence of the clientele specified by the agency's mission on agency action and some degree of coincidence of the viewpoints of the agency staff and the clientele" (Fortmann. 1990. p. 363). Indeed, this tendency was noted extensively in the USDA-CRAT report of 1997, particularly at the level of the decentralized local service office. Farmers in listening sessions "described a county committee system that shuts out minorities and operates for the favored few, where county officials ... have the power to 'send you up the road to fortune, or down the road to foreclosure"' (USDA-CRAT, 1997, p. 7). Furthermore, as the report continues, "employees [in this system] tend to be influenced by the values of their local communities and county committees rather than by national policies promulgated at the national level" (p. 18).

This system is further defined by its historic interdigitation with the agri-governance apparatus that solidified after World War II to serve the interests of a simultaneously emergent agribusiness sector. Defined by Pete Daniel as an "amorphous conglomeration of federal, state, county, and university components," this agri-governance struc- 
ture was "Captured by visions of large efficient farms, mindful that powerful farm organizations supported these goals, and aware of congressional pressure to aid wealthy farmers ..." (Daniel, 2013, pp. 12-13). At the local level, Daniel continues, the effect was a system in which "extension agents and program supervisors worked with successful farmers who could best take advantage of the latest scientific advancements" (p. 13). As Bonnie LynnSherow (2014) contends, in the case of both black and American Indian farmers in Oklahoma, the state's emergent agricultural extension apparatus served to consolidate white farmer dominance and further marginalize minority producers. As in much of the American South, agricultural research and extension in Oklahoma was racially segregated (Hargrove 2002, p. 32), with the state's original land grant institution, Oklahoma A\&M (now Oklahoma State University) serving the white farming population and Langston University, founded in 1897 as Oklahoma Colored Agricultural and Normal University, serving the black farming population (and later, other minority farmers). This situation had a direct correlate for American Indian farmers in Caddo County, where "white extension agents and farmers believed that the needs of Native farmers were being supplied by the Office of Indian Affairs" (Lynn-Sherow, 2014, p. 137), even as the BIA moved toward eliminating these programs in the 1940s.

This differentiated agri-governance system, however, is decidedly not an instance of separate but equal, with Langston following a common historical pattern among 1890 land grant colleges (those established under the second Morrill Act of 1890), wherein, as Lynn-Sherow (2014) notes, "black schools [received] far below their proportion of funding based on population" (p. 57). Paralleling this historical inequity, while Oklahoma's allocations for 2501 programs have been awarded overwhelmingly to Langston University (Rooke, 2015), this funneling of overall resources has in effect absolved Oklahoma State University's extension service-present in every one of the state's 77 counties_ — of any focused and mandated engagement with those producers targeted as "socially disadvantaged farmers and ranchers," thus perpetuating the system's entrenched segregation.
While the 2501 program has inherent problems, such as the competitive grant funding process that undermines solidarities essential to transformation of the larger system (Rooke, 2015), it nonetheless remains a central focus of some nonprofit organizations attempting to increase agricultural enterprises among American Indian landowners in southwestern Oklahoma, as in the story of Dana. Such organizations in southwestern Oklahoma have had a long history, and current efforts are often grounded in a renewed sense of the possibility for self-determination that farming and ranching present. The director of one such nonprofit said in an interview, "We don't have no manufacturing, no industries, nothing here to employ us. So people here are looking at ways to make use of their land, and one way is farming." Speaking about the influence of this group on local American Indian farming efforts, another research participant and member of the same group said, "[This] is the first group that has ever approached Natives, local Natives, and said, 'Hey, you can farm! You can take these classes, you can learn to be farmers, and you can farm your own lands! You can do this instead of other people doing it." Major obstacles to substantive achievement remain, however. While the struggle to deal with extreme climatic events is one challenge, even more central to the constrained adaptive capacity of American Indian producers with limited resources is a persistent lack of institutional access. Through significant examples drawn from ethnographic observation, integrated with interview excerpts from the current research, the next section will illustrate the dynamics that perpetuate differential access to knowledge and assistance that might otherwise yield greater resilience.

\section{Contemporary Ethnography of Vulnerability}

On an evening in the fall of 2015, one of the authors attended a meeting of a local 501(c)(3) organization devoted to assisting American Indian landowners in southwest Oklahoma, many of whom were seeking to farm their own land for the first time. The nonprofit director and meeting organizer, an American Indian landowner and former tribal liaison through Langston University's 2501 initiative, launched activities by welcoming 
everyone and asking one of the gentlemen present, an older American Indian man, to lead us off with a prayer. Then our host emphasized the group's primary interests in livestock production activities and associated USDA assistance programs, especially the 2501 programs. Agendas were then distributed, and the director and meeting host introduced the scheduled guest speakers.

First was a loan officer from the FSA division of the local USDA Field Office. His talk focused on FSA low-interest micro and youth loan programs. The former loan type is for amounts of US $\$ 50,000$ or less, he explained, and can be used for real estate, farm animals, equipment, or operating expenses. He emphasized that this loan program could finance, for example, start-up expenses for cow-calf operations, the primary interest of most of those present. This could include money for the purchase of heifers and costs associated with husbandry over the course of a calving season. Audience questions were quickly forthcoming. One attendee, whom we will call Jeff, a middle-aged man of mixed Comanche and Italian descent, asked about collateral, especially in instances where an individual has no significant assets to begin with. The speaker explained that in the instance of equipment purchases, the equipment itself could serve as collateral. But, he continued, approval is contingent upon a cash-flow analysis and the examination of three years of financial records. Though Jeff said nothing further at the meeting on this matter, in a later interview he offered comments that suggest the difficulties in operationalizing this seemingly simple process. Speaking of the recently rekindled desire among Native Americans to reap some direct benefits from their own land, land that has been in the productive control of non-Native lessees for more than a century, he says of the USDA, "They won't give us loans. We're just beginning farming now, and they won't give us loans because we don't have records. We don't have these things that other people do already, because they've been doing it and we haven't."

Another audience member inquired about the implications of a bulletin issued by the USDA communications office announcing the allocation of US $\$ 10$ million to support socially disadvantaged and veteran farmers and ranchers under the reauthorization of 2501 programs in the 2014 farm bill. Exhibiting limited knowledge of this announcement and its potential applicability in a county in which American Indians constitute a quarter of the population, the speaker responded that the approval process for FSA loans to individual producers is the same, regardless of race. However, the FSA Fact Sheet, "Loans for Socially Disadvantaged Farmers and Ranchers" clearly states: "Each fiscal year, the agency targets a portion of its direct and guaranteed farm ownership (FO) and operating loan (OL) funds to SDA [socially disadvantaged] farmers" (USDA FSA, 2011, p. 1). This can be considered to be an example of the disjunction of national and local level initiatives that the USDA-CRAT report identified almost 20 years ago.

A second meeting hosted by the group included speakers from the housing division of a neighboring county's USDA rural development office, another FSA representative, and a newly hired soil conservationist from the local NRCS office. All presenters from the USDA programs delivered informal overviews of specific loan and payment incentive programs. Beginning with the housing presenter, audience members expressed what through the evening became a nearly unanimous chorus of frustration at the realities faced by many American Indian landowners. It began with a simple question concerning required BIA approval for 504 loan and repair grants, as well as other programs. The FSA representative, upon concluding a thorough overview of the kinds of programs administered through the FSA and the assistance available through Emergency Conservation funds (used to repair damages caused by flooding and other severe disasters), was again confronted with expressions of frustration. Trust-land allottees, many in the audience agreed, are mostly unaware of these kinds of programs and are unsure where, how, or by whom they might be better informed. Many once again expressed frustration at the BIA's apparent negligence and/or indifference.

The NRCS programs representative was met with similar expressions of frustration, particularly directed toward the office's Environmental Quality Incentives Program (EQIP) allocations. Especially 
opaque to those gathered in the room was the process for determining priorities for disbursement of EQIP monies. The representative assured the audience that priorities were established via local input through public meetings. Audience members asked why they had never been aware of these meetings, and whose responsibility it is to inform them. The NRCS representative stated simply that these meetings are announced in local newspapers. Furthermore, NRCS's StrikeForce Initiative, a program recently extended to the state of Oklahoma, features targeted funds delivered through the EQIP program. The program's stated goal is “to increase USDA outreach to underserved populations and rural communities, while also improving access to and participation in USDA programs, as well as working to provide additional economic benefits to these areas" (USDA NRCS, Oklahoma, 2015, para. 2). Although Caddo County is identified as one of 32 in the state targeted for the StrikeForce initiative, NRCS staff at the Caddo County service center made no mention of this special program before an audience of American Indian farmers, although the Oklahoma StrikeForce initiative website features a short video, "StrikeForce in Indian Country," which might have served as a suitable orientation for that evening's presentation.

In a final and particularly poignant example from this meeting, an audience member we will call William shared his story of being thwarted in his efforts to take advantage of EQIP program funds. Because the funds are disbursed on a first-comefirst-served basis, he stated, by the time the BIA got around to reviewing his request, the EQIP funds were gone. In the meantime, he exclaimed with considerable indignation, all his non-Indian neighbors had new fences paid for through EQIP. As William later explained in an interview, multiple agencies coordinated relief efforts following a recent flood event. "This flood down here last year, last summer, knocked out miles and miles of fencing," at which point the coordinating agencies, "come in here [and] bless these guys and then they all got new fencing. Pretty. It's got leaves and weed hanging on it, but it's stretched tight. You go down the other way, where I'm at, Mr. Indian man, it's nasty looking [in disrepair]." Another research participant, whom we will call Matthew, a long- time agricultural consultant to the tribal peoples of southwestern Oklahoma and himself a local rancher, expressed a similar frustration: "The Emergency programs for floods-the Indian landowner could not qualify for those programs. . . Well, if they sent it down and they're funding [repairs from] flood damage and emergency-type situations, why aren't we qualified? We've been flooded just like everybody else." Later in the same interview, Matthew added, "What I've told a lot of landowners who asked me about those types of assistances, I said ... 'All I can tell is apply for it, ask for it, they'll just tell you no.' I said, 'I don't know why, I don't know the reason.' "

\section{Legacies of Bureaucratic Inertia}

The above examples are reflective of persistent larger patterns that reach back to the findings of the USDA-CRAT investigations of 1997. As the authors of the report wrote:

One example of a "broken" system is that field level employees, those closest to farmers, often work under an incentive system that is averse to serving minority and other small producers. Minority and small farmers said that their loans are processed too late, if at all, and that often "the money is gone" by the time they are approved. Field employees' performance ratings are often based on measurement systems that favor large, wealthy landowners ... USDA's policy statements support the idea of helping low-income and socially disadvantaged farmers. However, its management practices include performance measurement systems that actually do the opposite. (p. 8)

Many American Indian participants spoke of very similar personal experiences and their lasting influence. One participant, whom we will call Tom, spoke of his experience after returning from Vietnam:

After I did my tour of duty I went to this agriculture deal over here, where the farmers go [the USDA service center], and see if I could get a loan to get a tractor, plow, a brush hog and whatnot ... They told me they couldn't do 
it. I asked why, and they said ... How'd he put it?_-said 'You're Native American' ... .

Wouldn't even give me an application.

Jeff (mentioned above) spoke in strikingly similar terms:

Up until now the FSA department here in Anadarko, up until now, they don't service Native Americans . . Right now they're starting to because of all the lawsuits we've had against them ... It was [an] old boys society. They wouldn't wait on you; you go in to ask for an application, and they'd tell you, 'No, we don't have any,' or 'Go to the BIA, they're the only ones that can help you.' They'd just flat turn you down.

Later in the same interview, Tom spoke of the lasting impression such experiences left on him: "From my understanding, we weren't supposed to be denied [the opportunity to apply for this program], I found out afterwards. Regardless if you're Native American, you're black, you're Hispanic, you have that right [to apply], to get that loan to get started. Whatever you want to do-plant crops, bail hay, raise cattle on it-you have that right. But I said, well, I ain't messing with them over there [at the USDA office] anymore." Indeed, the experience of discrimination and the sense of "social defeat" it engenders create a powerful deterrent to future participation in such programs. The director of the local nonprofit organization, whom we will call John, stated: "[American Indians] had experienced so much racism and prejudice in these programs - they would not step in that office ... I had to be the person to walk them in there or take their paperwork in there. That's why I ... [started] doing their farm loans and all ... That's the barriers they were faced with. Once you're told no, as a Native American, you know, you'll withdraw ... It's changing, but it's not changing overnight." Others are more cynical about the future. Asking Jeff about USDA active initiatives for socially disadvantaged farmers, he replied: "I think right now it's mostly lip service ... because of the lawsuits the FSA and the USDA has been under... They put a lot of words out there saying, 'Oh, we're helping socially disadvantaged [farmers], we have all these programs,' but yet do they implement them? That's the question. We haven't seen it yet here in this area."

In another exchange, an older landowner of Kiowa descent, whom we will call Nick, put it this way:

I used to sell cars. Some guys are out there running the lot, and they chase every car that comes in. I used to have an old sales manager, and he said-remember this now- "You can't confuse activity with production.” Okay? Now, these [USDA] employees, they can be as active as you want, but somewhere in here you have to say, where is the measurement of production? No one's asking that question ... if you talk to them, they'll say, "Oh yeah, we got this paper out, and we give it to 'em, and gosh, look at how many applications we've got here" ... [But] where's the [proof of] production?

The situation is further exacerbated by a second layer of bureaucratic oversight, as most American Indian land is held in trust by the United States and thus falls under the management purview of the local BIA office. Another interviewee, whom we will call Don, offered this incisive assessment of the BIA's role as a land management entity:

Our trust lands are all managed by the BIA. BIA over the last 30, 35 years has begun to pull their technical and field people for conservation ... and put that money into the office, and administrative support. You don't have the [personnel] ... there to make sure the land is used properly, contracts are followed, maintenance is done. So your trust lands are really overused and not taken care of. Not all of them, but a majority of the lessees will use it, and if they can't make any money, they let it go, and they go get another lease. Well, that landowner is stuck with something they can't lease and if they do its abused because they have to abuse it to make money. So they're in a Catch-22. Then they turn around to the 
Bureau, and the Bureau don't have the technical assistance for them to find out, 'How do I take care of this?' because that's the first question these beginning farmers and ranchers have been asking.

Because of this situation, would-be beginning tribal farmers and ranchers perceive a series of obstacles from the start. These include not only concerns about failing conservation infrastructure in the form of broken terraces and failing flood control mechanisms associated with their belief that they will need to cope with the cost of mitigating decades of neglect by abusive lessees, but also their very real experiences with lack of access to the institutional support mechanisms that might assist in rebuilding these features.

Speaking of the willingness of many American Indian would-be farmers and ranchers to shoulder this burden anyway, Don continued:

They're taking care of their families, but they're also trying to take care of rebuilding land.

That's where we need a lot of help, but there's no help out there. Of course, NRCS and the Department of Agriculture are there to help us, but we have to qualify for their programs, or we can't get their technical assistance. And BIA has no technical assistance ... I think there is an MOU [Memorandum of Understanding] between the Department of Interior, BIA, and [the Department of] Agriculture to be that technical assistance for the Indian landowner. But . . . if that Indian landowner can't qualify or get a contract to do conservation work ... then there's no technical assistance there.

Continuing with this inquiry, I asked how much this difficulty was linked to non-overlapping bureaucratic calendars and program deadlines. He confirmed that this is a real problem and offered the following example:

Let's say you've got a program you can qualify for to do conservation work, but you've got to be in control of the land for, let's say, seven or eight years. Well, BIA has been doing three- year contracts and five-year contracts. Those long terms contracts that they need, they can't get, so they can't use that program, because they can't assure the Department of Agriculture that they're going to be in charge of that land.

In his final assessment, John offered,

Our biggest challenges, our biggest barriers to farming and ranching our own lands, has [sic] been the red tape, the politics that we have to go through in order to farm our own lands. The policies in place, they're outdated. It took me close to five years to farm my own landto farm my own land!- - because the Bureau of Indian Affairs didn't have no policies in place for a Native American farmer.

\section{Implications and Recommendations}

In order to practically address the issues discussed above, we suggest the following considerations for action:

(1) Address the bureaucratic rules in the BIA land trust system that make it difficult for Native American farmers to benefit from the same federal buffering system on which non-Native farmers are able to draw. It is unlikely that anything less than concerted, active, grassroots political pressure will result in these changes. However, there is a historical tension in place that complicates these suggestions. Quite simply, there is a perceived reason why these rules regarding trust and the intervention of the BIA exist-historically, too many Native American landowners, as their stake in their trust land was reduced due to fractionation through inheritance among multiple heirs, found it better to sell their land for quick income rather than to try to develop a smallscale farming venture that would compete poorly against larger, more heavily capitalized farms. At the same time, these policies are profoundly paternalistic and reflect a deeply problematic colonial history, an ongoing pattern of disregarding the agency of Native Americans. 
(2) Improve agricultural outreach in Oklahoma to mandate or encourage improved and appropriately designed agricultural extension services to Native American farmers, so that they become aware of the steps necessary to take advantage of grants and other programs available to farmers. We believe that there are aspects of the existing extension system and many other established federal systems to support agricultural development that reproduce a system of discrimination against Native American (and other minority) farmers. So although there are no Native American representatives on the local co-op board or the local NRCS board, we believe that there is potential to ensure that these organizations and institutions provide better information to and representation of the needs of small Native American farming ventures and Native Americans who seek to start farming. This can be achieved by ensuring that population-specific resources are provided by extension agents that will address the needs and concerns of Native American farmers. In addition, local co-ops and the NRCS board can be drawn into explicitly supporting Native American farming ventures by stressing their value as local business ventures.

(3) Provide informational resources to Native American farmer groups in the region that will permit them to provide their members with up-to-date programmatic information about federal and state resources and programs that can be mobilized both during normal years (when grants might help a farmer build a resilient infrastructure to prepare for drought) and during periods of disaster (rapid response grants that are often available to mitigate the impacts of specific disasters). This latter recommendation provides a way of ensuring that Native farmers have their own capacity and initiative regarding communicating with their members and tailoring their efforts to the needs of their members, something that statewide agricultural extension services are rarely able to do.

In addition to the above considerations, mem- bers of the larger research project from which this article derived have also proposed a Master Small Farm Advisor program to operate within Oklahoma Cooperative Extension Service (OCES) to bridge the gaps in trust and service between agricultural institutions and Native American populations. This program was conceptualized within the project's larger commitment to the development and implementation of decision support tools. The proposed program would use a service delivery concept comparable to one that already exists in OCES, the Master Gardener Volunteer program. The goal of the project is to use peer learning to offer minority and beginning/small-scale farmers the opportunity to increase their access to knowledge and programs that will help them maintain and grow their operations. Such a program, however, has proven difficult to establish, due to time and resource constraints within the OCES as well as poor community response to informational meetings. It is the hope of the researchers, however, that such a program may be implemented at a later date, perhaps with the assistance of a USDA small-producer grant. That future is, for now, in a holding pattern.

\section{Conclusions}

We have described many of the structural and political-economic conditions that have coalesced to undermine the possibilities available to American Indians who wish to pursue agriculture in the harsh climatic conditions of southwest Oklahoma. The experiences that our interviewees have faced, either personally or through the sharing of knowledge and experiences with other tribal and community members (O’Nell, 1996, p. 25), have shaped their attitudes vis-à-vis the government bureaucracies that were established, but often failed, to provide them with services, scientific advice, start-up loans, and various forms of social insurance to ensure that they can make it through hard times.

While there is a rich history of social scientists studying bureaucracies and/or people's experiences with bureaucracies, much of this has focused on how people have learned to adapt to or navigate them, or how they have been productively shaped (as Foucauldian citizen-subjects) by these bureau- 
cracies. In some cases, subjectivities are shaped through a conscious effort of "self-making" and performance in order to meet the demands of a bureaucracy (Silver, 2010); in other cases, subjects are shaped into citizen-subjects without their conscious knowledge or acceptance (Verdery, 1996); and, in still other cases, the act of evading or violating a bureaucracy can shape subjects and selves (Connolly, 1983). In this way, anthropologists have often documented how people have needed to become what a bureaucracy needs them to be in order to receive the services that that bureaucracy offers.

Our research with American Indians negotiating resource bureaucracies has shown that these agencies have worked to produce two things: first, a system that is structured to continue a history of discrimination against Native American farmers, and, second, a system that produces demoralization-actors who withdraw from participation in those very state-supported bureaucracies that were created to assist all farmers. Instead of shaping new, productive citizen-subjects by demanding that those subjects internalize bureaucratic logic and processes in ways that will change them, we have seen a system that has succeeded in setting up barriers that demoralize Native American farmers, leading them to be more likely to give up and walk away than to become the "productive" subjects the state seeks to shape (Friedman, 2007).

Like the example of ranchers in the Sulphur Springs Valley along the Arizona-Sonora border zone studied by Vasquez-Leon et al. (2003), the Southern Plains drought of 2010-2014 exposed differential vulnerabilities to climatic extremes. The buffering mechanisms built into contemporary disaster relief and assistance programs have facilitated a robust adaptive capacity (though perhaps not a sustainable one) by the conventional agricultural sector in a climatic zone that tends toward extreme climate variability and the ruin that often accompanies it. Resilience in southwestern Oklahoma, if defined as the ability to withstand severe disruptions, is limited to those best positioned to take advantage of the existing system of federal support programs administered through local resource bureaucracies. As this paper demonstrates, how- ever, most American Indian farmers in southwestern Oklahoma lack institutional access, leading to their increasing vulnerability.

This paper has also demonstrated that longterm patterns of discrimination in the delivery of services continue to characterize the experience of American Indian farmers in southwestern Oklahoma with local resource governance institutions. While the recent settlement of the Keepseagle classaction lawsuit against the USDA, like the Pigford case before it, has brought attention to these issues at the national level, change at the level of local service delivery has been less forthcoming. The reasons for this are numerous. First, local control of decentralized USDA service centers continues to be in the hands of the most capitalized conventional farmers, those most able to leverage government support programs as a buffer against extreme climate events and environmental disasters. This reality results in heightened vulnerability to these same conditions among other farming populations. Second, bureaucratic disjunction and/or inertia consistently work against American Indian farmers. In particular, disjunctions between the BIA and the USDA persistently disqualify and/or otherwise hinder Native farmers from taking advantage of support programs. Likewise, an opaque bureaucratic proceduralism attending both the administration of the BIA's land trust responsibility and the allocation program benefits from the local USDA service center constitute another barrier. The latter illustrates the final point here, and that is simply the persistence of discriminatory behavior in local service delivery, a trend noted consistently in the USDA's own assessment literature (Beatty-Davis, 1997). While the first and second points can be reformed through policy initiative, the latter condition is a matter of culture, and thus one far more difficult to change. In this regard, the words of John, whose struggles have been central to this paper, serve as a suiting conclusion: "In order to see change in the lives of people here ... people got to change, you know. People got to change. We all live together, we all live here together and everything, and we just got to get by the best way we can. We're living in a ugly, hard world-we're all trying to survive." 


\section{References}

Beatty-Davis, R. C. (1997). Conservation and culture: The Soil Conservation Service, social science, and conservation and Tribal Lands in the Southwest (Historical Notes No. 6). Washington, D.C.: U.S. Department of Agriculture, Resource Economics and Social Science Division. Retrieved from https://www.nrcs.usda.gov/Internet/FSE DOCUMENTS/stelprdb1043908.pdf

Connolly, W. E. (1983). Discipline, politics, and ambiguity. Political Theory, 11(3), 325-341. https://doi.org/10.1177/0090591783011003002

Daniel, P. (2013). Dispossession: Discrimination against African American farmers in the age of civil rights. Chapel Hill: University of North Carolina Press.

Fortmann, L. (1990). The role of professional norms and beliefs in the agency-client relations of natural resource bureaucracies. Natural Resources Journal, 30(2), 361-380. Retrieved from https://www.jstor.org/stable/24883577?seq=1

Friedman, J. R. (2007). Shock and subjectivity in the age of globalization: Marginalization, exclusion, and the problem of resistance. Anthropological Theory, 7(4), 421-448. https://doi.org/10.1177/1463499607083428

Green J. J., Green, E. M., \& Kleiner, A. M. (2011). From the past to the present: Agricultural development and Black farmers in the American South. In A. H. Alkon \& J. Agyeman (Eds.), Cultivating food justice: Race, class, and sustainability (pp. 47-64). Cambridge, MA \& London, UK: MIT Press.

Hargrove, T. M. (2002). A case study analysis of the implementation process of the Small Farmers Outreach Training and Technical Assistance (2501) Program, 1994-2001: Implications for agricultural extension education targeting African American farmers (Doctoral dissertation). Iowa State University, Ames. https://doi.org/10.31274/rtd-180813-8910

Jackson Lewis LLP, Corporate Diversity Counseling Group. (2011). Independent assessment of the delivery of technical and financial assistance: "Civil rights assessment" (Contract AG-3142-C-09-0030). White Plains, NY: Author. Retrieved from https://www.coalition4change.org/USDA\%20jackson.pdf

Johnson, R., \& Cowan, T. (2016). Local food systems: Selected farm bill and other federal programs. Washington, D.C.: Congressional Research Service. Retrieved from https://fas.org/sgp/crs/misc/R43950.pdf

Jones, H. S. (1994). Federal agricultural policies: Do Black operators benefit? Review of Black Political Economy, 22(4), 2550. https://doi.org/10.1007/bf02689978

Lynn-Sherow, B. (2004). Red Earth: Race and agriculture in Oklahoma Territory. Lawrence: University Press of Kansas.

Mittal, A. (2000). The last plantation. Food First Backgrounder, 6(1). Oakland, CA: Institute for Food and Development Policy. Retrieved from https:// foodfirst.org/wp-content/uploads/2013/12/BK6 1-Winter-2000-Vol-6-1-The-Last-Plantation.pdf

Oklahoma Climatological Survey. (n.d.). Climate of Oklahoma. Norman, OK: Author. Retrieved from http://climate.ok.gov/index.php/site/page/climate of oklahoma

O’Nell, T. D. (1996). Disciplined hearts: History, identity, and depression in an American Indian community. Berkeley \& Los Angeles: University of California Press.

Ribot, J. C., \& Peluso, N. L. (2009). A theory of access. Rural Sociology, 68(2), 153-181. https://doi.org/10.1111/j.1549-0831.2003.tb00133.x

Rooke, K. (2015). Getting our map together: Locating successes, gaps, and opportunities in USD A support for socially disadvantaged farmers and ranchers. Washington, D.C.: American University School of International Service \& National Family Farm Coalition. Retrieved from https://static1.squarespace.com/static/51624bdce4b058e82d8a2faf/t/555e29fce4b097314db315cd/143223449274 7/Getting+our+Map+Together+-+2501+Grant+Gap+Analysis+-+KROOKE.pdf

Silver, L. J. (2010). Spaces of encounter: Public bureaucracy and the making of client identities. Ethos, 38(3), $275-296$. https://doi.org/10.1111/j.1548-1352.2010.01145.x

Smith, T. F. (1996). The Caddos, the Wichitas, and the United States, 1846-1901. College Station: Texas University A\&M Press.

Stahl, R. J. (1978). Farming Among the Kiowa, Comanche, Kiowa Apache, and Wichita. (Unpublished doctoral dissertation). University of Oklahoma, Norman. Retrieved from https://shareok.org/bitstream/handle/11244/4434/7817915.PDF? sequence $=1$ \&isAllowed $=_{\mathrm{y}}$ 
U.S. Civil Rights Commission. (1965). Equal opportunity in farm programs: An appraisal of services rendered by agencies of the United States Department of Agriculture. Washington, D.C.: Government Printing Office. Retrieved from https:// files.eric.ed.gov/fulltext/ED068206.pdf

U.S. Department of Agriculture Civil Rights Action Team (USDA-CRAT). (1997). Civil rights at the United States Department of Agriculture: A report By the Civil Rights Action Team. Washington, D.C.: Government Printing Office. Retrieved from http://spencerdwood.weebly.com/uploads/1/8/0/5/1805891/crat_civil-rights-at-the-us-dept-ofag 1997 ocr 1-96 small.pdf

U.S. Department of Agriculture Farm Service Agency. (2011). Fact sheet: Socially disadvantaged farmers and ranchers loan. Washington, D.C.: Author. Retrieved from https://www.fsa.usda.gov/Internet/FSA File/sdaloans1108.pdf

U.S. Department of Agriculture Natural Resources Conservation Service, Oklahoma. (2015). USD A StrikeForce initiative in Oklahoma. Retrieved from https://www.nrcs.usda.gov/wps/portal/nrcs/detail/ok/programs/financial/eqip/?cid=nrcseprd338617

U.S. Government Accountability Office. (2008). U.S. Department of Agriculture: Recommendations and options to address management deficiencies in the Office of the Assistant Secretary for Civil Rights (Report No. GAO 09-62). Washington, D.C.: Author. Retrieved from https://www.gao.gov/assets/290/282835.pdf

VanWinkle, T. N., \& Friedman, J. R. (2018). American Indian landowners, leasemen, and bureaucrats: Property, paper, and the poli-technics of dispossession in Southwestern Oklahoma. American Indian Quarterly, 42(4), 508-538. https://doi.org/10.5250/amerindiquar.42.4.0508

Vasquez-Leon, M., Colin, T. W., \& Finnan, T. J. (2003). A comparative assessment of climate vulnerability: Agriculture and ranching on both sides of the U.S.-Mexico border. Global Environmental Change, 13(3), 159-173. https://doi.org/10.1016/s0959-3780(03)00034-7

Verdery, K. (1996). The "etatization” of time in Ceauşescu's Romania. In K. Verdery, What was socialism, and what comes next? (pp. 39-57). Princeton, N.J.: Princeton University Press. https://doi.org/10.1515/9781400821990-003 